\title{
The Application of Empty Palm Fruit Bunch (EPFB) As a Material for Fixed Wing Type Unmanned Aerial Vehicle Fuselage Production
}

\author{
Muhammad Teguh, ${ }^{\mathrm{a},{ }^{*}}$ Kaspul Anuar, ${ }^{\mathrm{a}}$ Muhammad Taslim, ${ }^{\mathrm{a}}$ and Rexy Guruh Saputra, ${ }^{\mathrm{a}}$ \\ a) Mechanical Engineering Department, Universitas Riau, Indonesia \\ *Corresponding author: muhammad.teguh2265@student.unri.ac.id
}

\section{Paper History}

Received: 26-May-2019

Received in revised form: 28-October-2019

Accepted: 30-November-2019

\begin{abstract}
One of a potential application of Empty Palm Fruit Bunch (EPFB) is the material of fuselage on Unmanned Aerial Vehicle (UAV). This study was been began by Alkali Treatment on EPFB. Then, the fuselage was molded using Vacuum Bagging Method. There are three unit of mold with combination of fiberglass + carbon fiber, fiberglass + EPFB fiber and full EPFB fiber. The measurement show fuselage with hybrid composite material (fiberglass and EPFB) has the lightest mass of 559 gram. Deflection test of all three fuselages show that the maximum deflections were been under $1 \mathrm{~mm}$. Next, the Static Impact Test show no damages or cracks on all three fuselages. The result of Flight Test show all fuselages could do well fly and survive belly landing.
\end{abstract}

KEY WORDS: Empty Palm Fruit Bunch, Fuselage, Composite, Alkali Treatment.

\section{NOMENCLATURE}

EPFB Empty Palm Fruit Bunch

BPS Badan Pusat Statistik

UAV Un-manned Aerial Vehicle

psi Pressure

\subsection{INTRODUCTION}

Riau is a province with the biggest Palm Oil Plantation in Indonesia. According to BPS in 2015, Riau has 2,424,545 hectares of Palm Oil Plantation. Beside fresh palm fruits, those plantation also produce a lot of empty palm fruit bunches and palm shells as wastes. Approximately, Riau produce 1099.3 tons of solid waste every day [1]. Commonly, these wastes were processed to compost, organic charcoals, active carbon, and also fuels for boiler on Palm Oil Factories [2].

Currently, studies about EPFB start pointing to material topics on natural composites (natural fiber).The EPFB waste contain celluloses within $43 \%-65 \%$ and lignin within $13 \%-25 \%$ for composite board production [3]. The PFB fiber is also suitable for combination with polymers such as natural rubber, polypropylene, polyvinyl chloride, and phenol formaldehyde and epoxy resin. In addition, the EPFB toughness is so high that makes it ideal for multiple applications on engineering scopes $[3,4]$.

One of a potential application of Empty Palm Fruit Bunch (EPFB) is the material of fuselage on Unmanned Aerial Vehicle (UAV) production. Fuselage used to be made of conventional composites of fiberglass and carbon fiber combination as the main material. Fiberglass and carbon fiber are expensive, it makes production cost soared. Beside costs, according to researches, direct contact between labors and these fiber micro particles dust is badly impact for health in a long run [5].

Considering these facts, the research team plan to make a study about EPFB as a substitute material for fuselage of UAV. The aim is to discover the mechanical properties and physical properties such as the fuselage mass, toughness to survive impacts, deflections and advisability to be the main material of UAV's fuselage. This study is expected to add sale values, enhance technology development and reduce production costs for UAVs on military, disaster prevention, and humanity. 


\subsection{BASIC THEORY}

\subsection{Empty Palm Fruit Bunch}

The Empty Palm Fruit Bunch (EPFB) is a composition of residual fibers of the fresh palm fruit sterilization (under vaporization of $294 \mathrm{kPa}$ within an hour). EPFB is cheap, easily decomposed and non-toxic natural fiber that used broadly. EPFB is a natural material that contains thick and rough filaments. This make EPFB is more effective than industrial materials that are not renewable, bad for health and environment, and expensive for small scale production. The use on polymer composites could solve environmental problems, especially for palm oil wastes. EPFB micro-structure is shown in Figure 1.

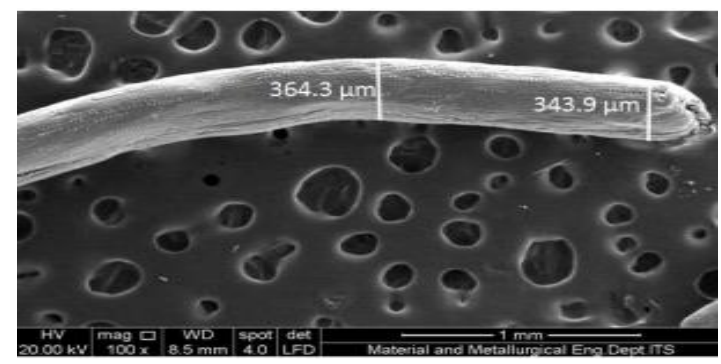

Figure 1: Sketch of Empty Palm Fruit Bunches [6].

\subsection{Empty Palm Fruit Bunch Potency}

Riau is a province with the biggest Palm Oil Plantation in Indonesia. According to BPS in 2015, Riau has 2,424,545 hectares of Palm Oil Plantation [7]. Beside fresh palm fruits, those plantations also produce a lot of empty palm fruit bunches and palm shells as wastes. Approximately, Riau produce 1099.3 tons of solid waste every day [1].

\subsection{Composite}

Composite is a material made from two or more constituent material with significantly different physical and chemical properties that, when combined, produce a material with characteristics different from the individual components. Composite consist of fiber (reinforcement) and matrix. The matrix protects the fibers from environmental and external damage and transfers the load between the fibers. The fibers in turn, provide strength and stiffness to reinforce the matrix - and help it resist cracks and fractures. Form of composite material is shown in Figure 2.

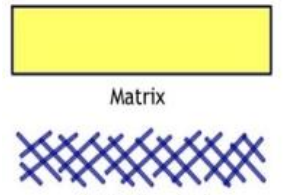

Reinforcement
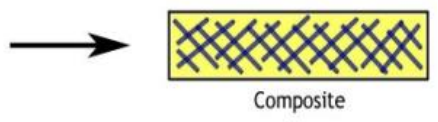

Figure 2: Matrix and Reinforcement [8].

Selection of reinforcement is very important because it decide how powerful the product is. Reinforcement also decides how much resin will be used.

\subsection{Vacuum Bagging}

Vacuum bagging is a method to produce composite material by using the atmospheric pressure clamp and press the laminated layers evenly [9]. The process was begun by sealing the laminated composite in impermeable bag. The bag is impermeable mold at one side and impermeable bag at the other side. When the bag is sealed to the mold, the pressure outside and inside the bag is equal to the atmosphere pressure: about 29 inch mercury $(\mathrm{Hg})$, or $14.7 \mathrm{psi}$. Then the vacuum pump suck the air from inside the bag, the pressure inside the bag reduced while outside the bag remain 14.7 psi. The atmospheric pressure presses the bag and all the things inside the bag equally [9].

The fuselage production is referred to the Fixed Wing type UAV Atha Mapper 2150[10]. The fuselage is molded into three units with different materials. The first fuselage is molded using fiberglass and carbon fiber. The second is molded using fiberglass and EPFB. And the last is molded fully using EPFB. After being molded, the fuselage is finished by soft and rough putty [11]. Picture 4 is shown the result of the fuselage production.

\subsection{RESEARCH METHODS}

\subsection{Research Process}

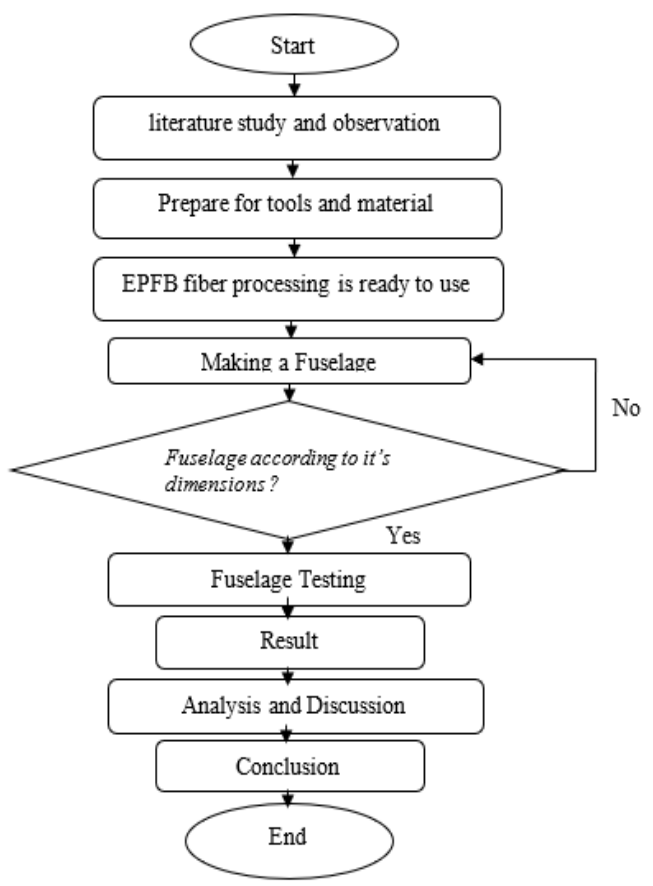

Figure 3: Flow Chart of Research Implementation Methods.

\subsection{Technique of Making Unmanned Aerial Vehicle Fuselage}

The fuselage production is referred to the Fixed Wing type UAV Atha Mapper 2150. The fuselage is molded into three units with different materials. The first fuselage is molded using fiberglass and carbon fiber. The second is molded using fiberglass and EPFB. And the last is molded fully using EPFB. After being 
molded, the fuselage is finished by soft and rough putty. Figure 4 shows the result of the fuselage production.

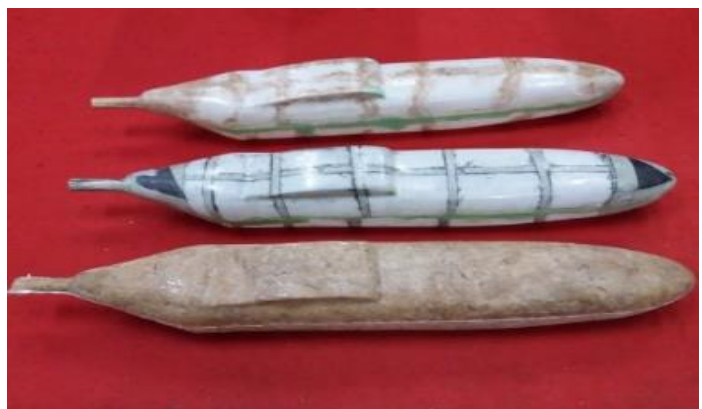

Figure 4: The results of making three Fuselage Unmanned Airplanes with different materials.

\subsection{Data Acquisition Technique, Data analysis and} Interpretation

After the fuselage is being made, the mass of each fuselage is measured. Next, the deflection is measured that happen along the longitudinal axis of the fuselage ( $\mathrm{x}-$ axis). To know the ability to resist impact load due belly landing, Static Impact Test is required. Static Impact Test is done by using a pendulum that represent a free fall fuselage over 1.5 meter (hard landing). Lastly, flight test is done to evaluate the ability of the fuselage to survive belly landing.

\subsection{RESULTS AND DISCUSSION}

\subsection{Measurement of Fuselage Mass}

Result of mass measurement of all three fuselage shown in Figure 5 .

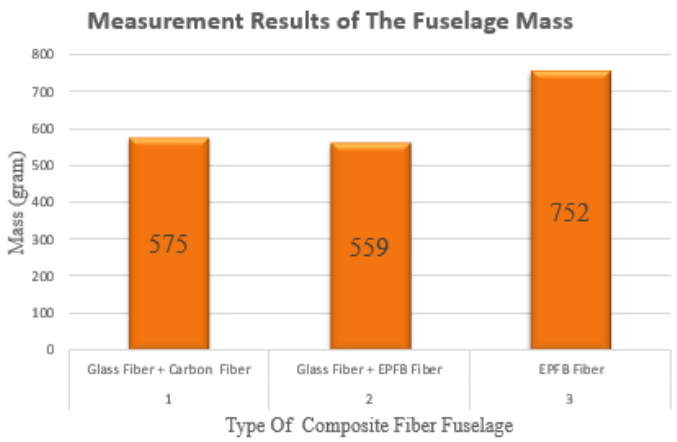

Figure 5: Measurement Results of Fuselage Mass.

Figure 5 shows fuselage with Fiberglass and EPFB has the lightest mass of 559 grams. While the highest mass is the fuselage with full EPFB of 752 grams. Fuselage with fiberglass and carbon fiber combination has a mass of 575 grams.

\subsection{Deflection on Fuselage}

From deflection measurement, fuselage with fiberglass and carbon fiber combination has the smallest deflection. Followed by the fiberglass + EPFB and the highest by the fully EPFB composition. The result is shown in Figure 6.

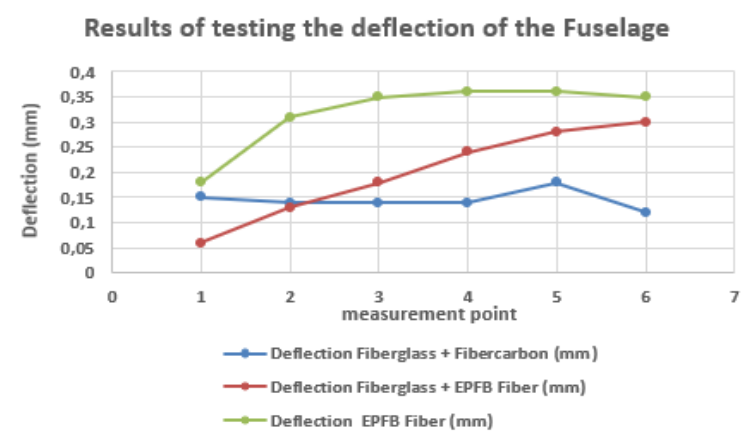

Figure 6: Deflection Test Results of all three fuselages.

\subsection{Static Impact Test}

This test use a pendulum with $6 \mathrm{Kg}$ mass and was set at $1.125 \mathrm{~m}$ tall. This condition represent a $4.5 \mathrm{~kg}$ UAV diving from $1.5 \mathrm{~m}$ latitude (hard landing). The result show no damages or cracks. The result is shown in Figure 7.

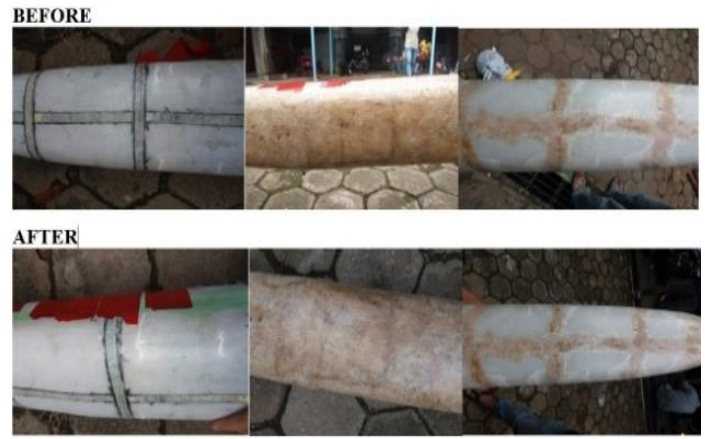

Figure 7: Before and After Tests of Static Impact in the Three Types of Fuselage.

Table 1: Result of Static Impact Testing

\begin{tabular}{|c|c|c|}
\hline \multirow{2}{*}{ No } & \multicolumn{2}{|c|}{ Static Impact Test Result } \\
\cline { 2 - 3 } & Composition & Visual Result \\
\hline 1 & Fiberglass + fiber carbon & No damages/cracks \\
\hline 2 & Fiberglass + EPFB & No damages/cracks \\
\hline 3 & EPFB & No damages/cracks \\
\hline
\end{tabular}

\subsection{Flight Test}

This test is done to know the ability of the fuselage to receive aerodynamic load and impact load on landing with real condition. From the test, all the fuselage could do a well flight from take off until landing. The process of the test is shown in Figures 10, 11, and 12 .

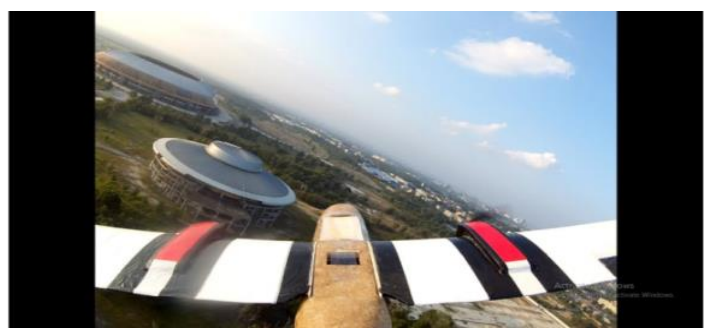

Figure 8: Fuselage Empty Palm Fruit Bunch Fiber. 


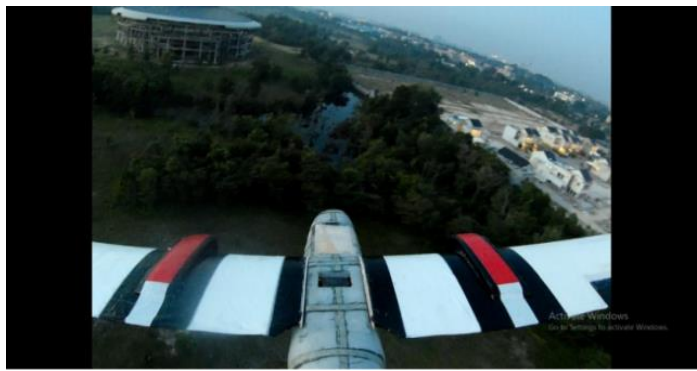

Figure 9: Fuselage fiber carbon and fiberglass.

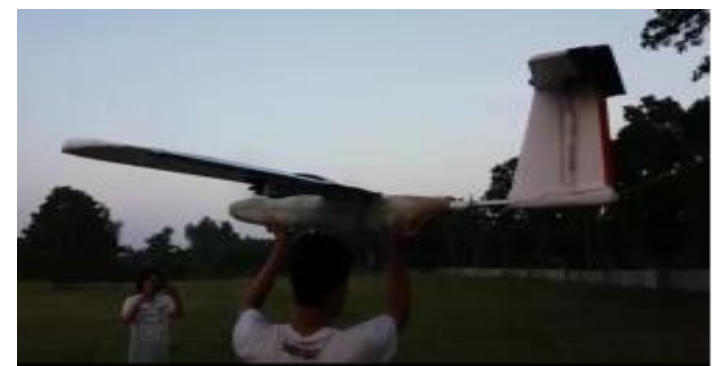

Figure 10: Fuselage from Fiberglass and Empty Palm Fruit Bunch.

Table 2: Test Result of Landing with Belly Method

\begin{tabular}{|l|l|l|}
\hline \multicolumn{3}{|c|}{ Test Result of Belly Landing Without any Landing Gear } \\
\hline No & Composition & Visual Result \\
\hline 1 & Fiberglass + Carbon Fiber & No damages/cracks \\
\hline 2 & Fiberglass + EPFB & No damages/cracks \\
\hline 3 & EPFB & No damages/cracks \\
\hline
\end{tabular}

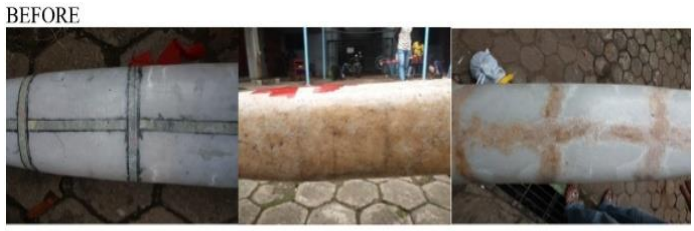

AFTER

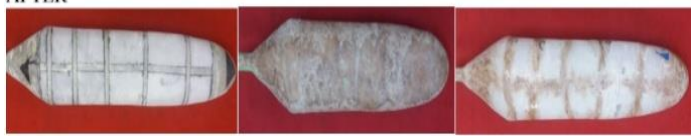

Figure 11: Before and After Landing with Belly Method in the Three Types of Fuselage.

\subsection{CONCLUSION}

From all the test, fuselage with Fiberglass-EPFB combination has the lightest mass of 559 grams. Next, the deflection from all fuselages are very low with not exceeding $0.5 \mathrm{~mm}$ from maximum boundary of $10 \mathrm{~mm}$. This show all units fulfill the prerequisite of an UAV fuselage. Impact test show no damages or cracks. And the last test show that all three units could do a well flight. This conclude EPFB could be a main alternative material on UAV fuselage production.

\section{ACKNOWLEDGEMENTS}

Advance gratitude to Allah SWT. Thanks to the guide lecturer and Serindit Aero Team that have lending their hands along this research.

\section{REFERENCE}

1. Lusiani, R., Sunardi and Ardiansyar, Y. (2015). Pemanfaatan Limbah Tandan Kosong Kelapa Sawit Sebagai Papan Komposit dengan Variasi Panjang Serat. Jurnal Teknik Mesin Untirta. 1(1), 46-54.

2. Nugroho,G., and Budiana, O. (2017). Pengaruh Teknik Isolasi terhadap Kekuatan Tarik dan Lengkung Material Komposit pada Pembuatan Fuselage Pesawat Tanpa Awak. BKSTM-Indonesia. 9, 40-47.

3. Rahmat, Zarli R. and Badri, M. (2018). Studi Karakteristik Kekuatan Tarik dan Harga Impak Material Polymeric Foam Sandwich Panels Komposit dengan Variasi Perlakuan Serat Tandan Kosong Sawit. JOM- FTEKNIK. 5(1), 1 - 8.

4. Savetlana, S. and Andriyanto, A. (2012). Sifat-Sifat Mekanik Komposit SeratmTKKS Poliester. Jurnal Mechanical. 3(1), 45-50.

5. Achille S., Sismonetta G. and Massimo F. (2010). Fiberglass dermatitis Clinics in Dermatology, Volume 10, Issue 2, April-June 2010, 167-174.

6. Rahmasita, E,M., Farid, M. and Ardhyananta, M. (2017). Analisa Morfologi Serat Tandan Kosong Kelapa Sawit Sebagai Bahan Penguat Komposit Absorpsi Suara. Jurnal Teknik ITS. 6(2), 2337-3520.

7. Badan Pusat Statistik Provinsi Riau (2015). Luas Areal Perkebunan Kelapa Sawit. Riau: Badan Pusat Statistik.

8. Estu Nugroho, G. (2017). Karakteristik Komposit Berpenguat Serat Tandan Kosong Kelapa Sawit Menggunakan $\mathrm{NaOH}$ dengan Fraksi Volume 4\%, 6\%, dan 8\%. Skripsi. Fakultas Sains dan Teknologi, Universitas Sanata Dharma, Yogyakarta.

9. Anonim (2011). Vacum Bag Process. http://mymachining.blogspot.co.id/2012/01/vacuum-bagprocess.html. Accessed 18 April 2018.

10. Nugroho,G., and Budiana, O. (2017). Pengaruh Teknik Isolasi terhadap Kekuatan Tarik dan Lengkung Material Komposit pada Pembuatan Fuselage Pesawat Tanpa Awak. BKSTM-Indonesia. 9, 40-47.

11. Haryanti, A., Norsamsi., Sholiha, P. and Putri, N. (2014). Studi Pemanfaatan Limbah Padat Kelapa Sawit. Konversi. $3(2), 20-29$. 